\title{
特 集口最新の放送技術
}

\section{2. トータルディジタル化への展開 \\ 2-1 システム}

\section{2-1-1スタジオのディジタル化}

\section{1. まえがき}

\section{1 ディジタル単体機器の出現と普及}

スタジオ映像機器のディジタル化は昭和 50 年頃か ら商品化され，当初はフレームシンクロナイザ(FS)， ディジタル特殊効果装置 (DVE) 等のスイッチャ周辺 単体機器が中心であったが, 昭和 57 年にディジタル 映像スイッチャが運用開始され，現在に至っている

\section{2 映像スイッチャのディジタル化 ${ }^{1) \sim 31}$}

映像スイッチャのディジタル化においては，スイッ チャ内の映像ルートによる特性の変化がなく常に安定 である，日常メンテナンスがほとんど不要でランニン グコストが安い, 特殊効果装置 (DVE) とディジタル 的に結合でき,さらにデフォーカスなどの光学系処理 であった特殊効果も行えるなどのメリットがあった その反面, 当初は消費電力, 発熱, 遅延時間, コス ト，さらに性能では特にクロマキー装置に問題があっ た

しかしながら，ディジタル映像スイッチャも開発か ら 10 年を経て, 前記の問題は大幅に改善されている

表 1 は, アナログスイッチャとディジタルスイッチャ の比較を示す4)

本稿では，スタジオ機器の中枢であるスイッチャを 中心に，スタジオディジタル化の現状，技術動向およ び今後の展開について以下に述べる

\section{2. スタジオディジタル化の現状}

\section{1 トータルディジタル化への足掛かり}

スタジオ機器の中枢である映像スイッチャがディジ

†松下通信工業株式会社

"2 Total Digitalization, 2-1 Systems, 2-1-1 Digital Video System for Studı" by Kazuakı Irıe (Matsushita Communı cation Industry, Yokohama)
正会員 入 江 和 章 $^{\dagger}$
タル化され，すでに周辺機器がディジタル化されてい る状態から, 次はスイッチャと各機器間の接続や, 室 間をアナログ信号からディジタル信号の状態で接続す る,トータルディジタル化が進んでいる

アナログ信号での接続では, 入力信号には A/D変 換器が, 出力信号には D/A 変換器が設けられてお り, 信号の特性はこれらの変換器に左右されていた さらに機器間を接続することにより $\mathrm{A} / \mathrm{D}, \mathrm{D} / \mathrm{A}$ 変換 器を複数通るため特性を悪化させていた ディジタル 信号での接続では, これら変換器での変換誤差や量子 化ノイズ等の発生をなくすとともに，安定な性能を維 持することができる

さらに，映像信号の記憶媒体であるVTR がディジ タル化 (D 1, D 2, D 3 規格) され，トータルディジ夕 ル化の傾向が加速されている

\section{2 ティジタル化の採用度合}

最近のスタジオ(制作, ニュース, 中継車等)の新 設，更新におけるアナログスイッチャとディジタルス イッチャの採用化率は，アナログ $20 \%$ に対しディジ タルは 80\%であり，ここまでディジタルスイッチャ が定着しており，アナログスイッチャは小規模なニュ 一ス, 中継車システムに限られてきている 規模が大 きくなるほどディジタル化のメリットが増えることも 採用度合を上げている

\section{3 信号方式}

信号方式には，コンポーネント方式とコンポジット 方式がある、コンポーネント方式は高画質を維持する ことができ，特にキー合成時の処理などではコンポジ ット方式との差は大きいが, 設備投資が高額なため, コマーシャルビデオ等の編集を目的とするスタジオ， いわゆるポスプロ部門に限定されているしかしなが ら, 高画質・高品位の映像の要望が高まり, ハイビジ ヨン, 第 2 世代 EDTV 等のコンポーネントアイラン

テレヒション学会誌 Vol 46, No 4, pp 400 403 (1992) 
表 1 アナログ・ディジタル比較表

\begin{tabular}{c|l|l}
\hline \hline & \multicolumn{1}{|c|}{ アナログ } & \multicolumn{1}{|c}{ ディジタル } \\
\hline & 性能が良い (特にクロマキー) & 特性が安定である \\
& チャンピオンデータが作り出せる & 最短・最長ルートによる特性の変化なし \\
& ユーザー側での保守が可能 & 日常メンテナンスがほとんど不要 \\
$\times$ & 低消費電力 & ランニングコストが安い \\
リ & 価格が安い & DVEとの有機的な結合が行える \\
ト & & マイクロコンピュータとの結合性が高い \\
& & カードチェンジによる復旧が可能 \\
& & 品質の均一性が保て, 作りやすい \\
& & 技術の再利用が可能 \\
\hline デ & 経年変化による特性の劣化がある & 消費電力が大 \\
メ & 日常メンテナンスが必要 & 遅延時間が大 \\
ツ & カードチェンジ後の調整が必要 & イニシャルコストが高め \\
ト & 熟練技術者の調整が必要 & \\
\hline
\end{tabular}

ドの構想が運用および検討されている.

ニュース, 中継, ドラマ等の番組制作を目的とする スタジオには, イニシャルコスト, ランニングコスト とも経済的に有利なコンポジット方式のシステムが採 用されている。

\section{4 伝送方式}

伝送方式には, 従来のアナログ方式から単体機器を 中心にディジタル化されている．ディジタル信号方式 にはパラレル方式とシリアル方式がある，パラレルの ディジタルインタフェースについては, コンポーネン ト/コンポジットとも CCIR, SMPTEにて規格化さ れている。

コンポジットパラレルインタフェースは, クロック $\left(4 f_{S C}\right)$ とデータ (10ビット) をツイストペア線で D サ ブ 25 ピンのコネクタにて受け渡しを行うため, 伝送 距離, 接続換え等に欠点があり, クローズされたシス テムに限られている。

シリアルインタフェースには $10 \mathrm{~B} 1 \mathrm{C}$ 方式と SMPTE T 14.224 のスクランブル方式があり, 両方 式とも伝送路に既存の同軸ケーブルを使用できること が特長である。

\section{3. 技 術動 向}

\section{1 素子・回路技術の現状と動向}

当初のディジタル IC といえば TTL の S シリーズ, F シリーズが主流で, そのため大消費電力と熱発生が 問題であった。その後 CMOS技術が進み, 汎用 IC からメモリーまで高速化され実用に至り, 消費電力の 低減が図られてきた。

最近では CMOS プロセス，Bi-CMOS プロセスで の ASIC 化, PLD 化 IC が採用されている. ASIC 化

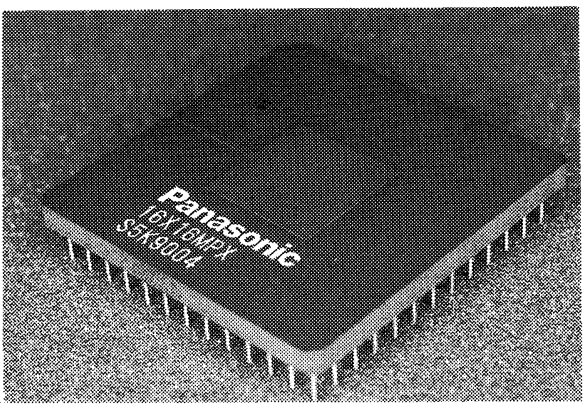

写真 $116 \times 16$ マトリックススイッチ LSI

により高密度実装化が実現し, 装置の小型化, 低消費 電力化が図られている.PLD化は, 開発期間の短縮, 変更が容易であることから多く採用されている.

性能面に扔いては, これまでのディジタル化回路技 術は, 従来のアナログ回路をもとにディジタル化して きたため, 性能的にビット精度が問題になり, どうし てもアナログ回路に追い着けなかった。そこで特に内 部発生源であるワイプ, キー,スーパー等に新たな画 像処理アルゴリズムを構築することで, 少なくともア ナログと同等およびアナログを超える性能が得られる ようになると思われる。近年では, 高速画像イメージ プロセッサによるシミュレーションで, AI 処理やニ ユーラルネット処理など, 高度化しつつあるアルゴリ ズムが実証されている5).

シリアルインタフェース対応には, コンポジット信 号では $143 \mathrm{Mb} / \mathrm{s}(\mathrm{SMPTE}) \sim 157 \mathrm{Mb} / \mathrm{s}(10 \mathrm{~B} 1 \mathrm{C})$, コンポーネント信号では $270 \mathrm{Mb} / \mathrm{s}$ 以上のスピードを もった素子が必要である。一般的には ECLを使用す るが, ASIC化となると消費電力, 放熱に課題が残 


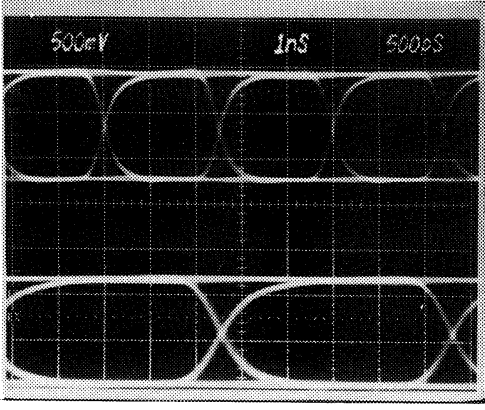

$\left(\begin{array}{ccr}500 \mathrm{mV} / \mathrm{div} & \mathrm{Up} & 1 \mathrm{~ns} / \mathrm{div} \\ & \text { Down } & 500 \mathrm{ps} / \mathrm{div}\end{array}\right)$

写真 $2400 \mathrm{Mb} / \mathrm{s}$ 出力波形

る。

そこでECLに代る素子として GaAs(ガリウム砒 素）によるASIC 化が実用化されている．写真 1 は $\mathrm{GaAs}$ 半導体を用いた $400 \mathrm{Mb} / \mathrm{s}$ 対応シリアル信号用 の $16 \times 16$ マトリックススイッチ LSI の一例である ${ }^{6)}$. 写真 2 は $400 \mathrm{Mb} / \mathrm{s}$ の出力波形である. GaAs 半導体 を用いた LSIは, 今後高速化を要求されるハイビジ ヨン用機器, 第 2 世代 EDTV 等に欠かせなくなると 思われる。

\section{2 制御・ソフトウェア技術の現状と動向}

スタジオの制御は 2 つ大別される。ひとつは, 各 単体機器内の制御であり, ひとつは各機器間を制御す るものである.

各機器内の制御ではますますソフトウェア処理が増 大している. 従来のアナログスイッチャでは, ボタン 情報とアナログのボリューム電圧值を操作部から送 り, 制御部で加工処理していた。ディジタル化された スイッチャや特殊効果装置の操作部は, 少ないボタン の組合せで多くの操作モードを実現するため，膨大な 情報を送らなければならない．

ここで, 最新のディジタルスイッチャの操作部の構 成を例にあげる，操作に関する部分は操作部で，映像 信号に関する部分は制御部でソフトウェア処理され， 多くの情報が, より敏速に処理されている. しかし, 1 つの CPU(マイクロコンピュータ) の能力には限界 があるため, 操作部は各機能ブロック単位に CPUを 装備し分散化処理され，1つのシリアル回線でメイン の CPU と接続している.メイン CPU は各パネルブ ロックの情報を管理し制御部や外部機器との通信の効 率を上げている. 分散化された操作部はシリアル回線 で接続されているため, 機能ブロック単位の拡張が容 易である、また, パネルブロックの配置を自由にし，

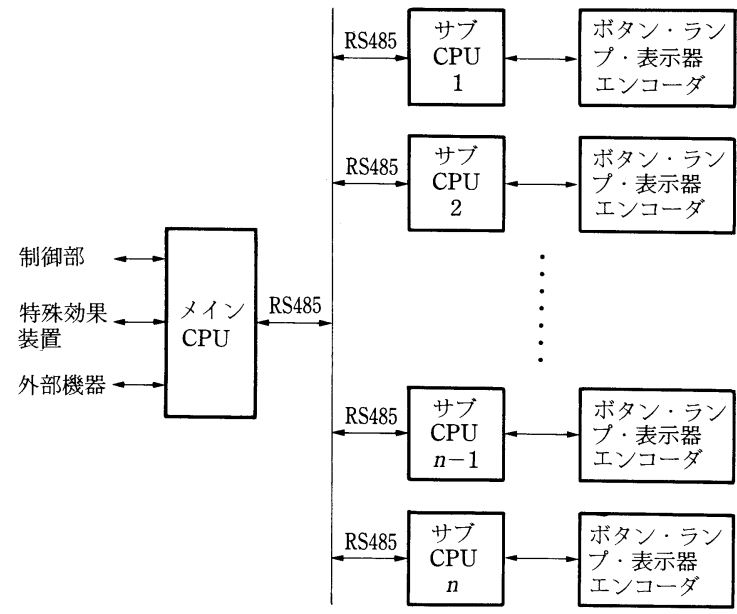

図 1 分散処理のスイッチャ操作パネル例

中継車などでの部分持ち出しを容易にしている．図 1 は分散化処理によるスイッチャの操作パネルの系統例 である。

各機器間の制御においては, 局内の運行系ホストコ ンピュータの管理下に置かれ制御される運用体系があ る. スタジオ内の対象機器はプリセットスイッチャや ニュースサブスイッチャ等である。これらは運用系コ ンピュータと制御 LAN 等により接続されることが多 い.

\section{4. 今後の展 開}

\section{1 機 能}

スイッチャ, DVE 等の特殊効果機能としては, 各 社しのぎを削り開発を進めてきたが, 現状で製品化が 可能な特殊効果としては出つくした感がある.

今後は, 人の手で行われていた調整を, 自動化によ り正確および敏速に解決することであると思われる。 下記にその代表的なものをあげる.

・自動位相調整：1H AVDLによる自動調整と位 相状態の警告表示

・キー調整：入力信号レベルに対して最適化調整

・自動照明調整：番組プログラムによる照明の自動 化

・自動アンテナ調整：中継スケジュールによる自動 方向調整

\section{2 マンマシンインタフェース}

マンマシンインタフェースとしては, より人間の感 性に則した各種機器の操作性を実現するとともに, 今 まで一目で確認できなかった信号状態等を表示するな どの運用サービス性があげられる，下記にその代表的 
なものをあげる。

操作性（スイッチャ）

・番組に応じてボタン等の機能が変身する：クロス ポイントボタンの割付と表示等

・メモリー機能の完全なプレビュー表示：NEXT 画面を映像にてプレビュー

\section{運用サービス性}

・信号状態の表示：信号および位相の良否状態，警 告表示

・信号の ID データ表示：信号の配信元・配信先表 示，信号の番組名・放送日・放送時間表示

\section{5.むす び}

スタジオ内のスイッチャを中心に執筆したが，スイ ッチャ周辺機器も殆んどがディジ夕ル化されており, トータルディジタル化が現実のものとなってきてい る。さらに新たなアルゴリズムの確立によってアナロ グ回路より優れた性能が実現されることと思われる。

終りに,ディジタル機器の導入に対してご理解とご
指導を承り育てあげていただきました NHK，民放各 局に深く感謝いたします。

(1991 年 12 月 2 日受付)

\section{〔参 考 文 献〕}

1）“ディジタル対アナログ”, 放送技術, 41, 1, pp. 59-82（Jan. 1988)

2）“ディジタル対アナログ”，放送技術，41，5，pp. 59-70（May 1988)

3）“ディジタル対アナログ”，放送技術，41，6，pp.73-82（June 1988)

4）鈴木ほか：“ディジタルビデオスイッチャDVS 3”，放送技 術, 42, 8, pp. 76-80 (Aug. 1989)

5）論文特集“画像処理一アルゴリズムとシステム一”, テレビ誌, 45, 10, pp. 1146-1287 (Oct. 1991)

6）福田ほか：“広带域 SDN 用 ATM スイッチの試作”，信学技 報, SSE-174

\section{2-1-2＼cjkstart送出システムのディジタル化}

正会員 田 上 博 康 $^{\dagger}$, 正会員 濱 島 力 $^{\dagger}$
正会員 中 島 広 志 $^{\dagger}$

\section{1. まえがき}

近年, 放送局の番組編成の多様化に伴い送出システ ム（以下，マスターシステムと呼ぶ）においては入力 素材が増加し, また柔軟な信号処理が要求されてきて いる.

さらに 24 時間放送対応など, システムの規模が大 きくなっても安定度, 信頼度が確保され, なおかつ EDTV やHDTV などの高品位化の動向を踏まえ, 高性能化への拡張性も望まれている.

現在, ディジタルインタフェース規格は, ビットシ リアルについては規格化の方向であり，また，ビット パラレルについては SMPTE(Society of Motion Pic-

$\dagger$ 日本電気株式会社 放送映像事業部

"2-1-2 Digital Master System" by Hiroyasu Tagami, Chikara Hamasima and Hiroshi Nakajima (Broadcast and Video Equipment Division, NEC Corporation, Tokyo) ture and Television Engineers）のパラレルフォーマ ットが国際的に規格化されている．音声については AES/EBU(Audio Engineering Society/Europian Broadcasting Union) フォーマットが国際統一規格と なっている.

また局内システムに扔いては，番組制作スタジオシ ステムにおけるプロダクションスイッチャは数年前か らディジタル化が進んでおり，その周辺機器である VTRもディジタル出力を備えたディジタル VTRが 各放送局で盛んに導入されてきている．これらのディ ジタル化の波にのり, 局内トータルディジタル化の要 求が高まり，その中でマスターのディジタル化も不可 欠なものとなってきた。

本稿では, マスターの映像系システム, 音声系シス テムのディジタル化の基本設計方針の概要を述べると ともに，本システムを構築するために開発した主要な ディジタル機器について紹介する. 